\title{
A minimal dose of unmanipulated bone marrow infusion without conditioning for T-B+NK- severe combined immunodeficiency
}

\author{
Eun Sang Yi ( $\sim$ holypresent@naver.com ) \\ Korea University Guro Hospital https://orcid.org/0000-0001-8214-2106 \\ Hee Young Ju \\ Korea University Guro Hospital \\ Hee Won Cho \\ Korea University Guro Hospital \\ Ji Won Lee \\ Korea University Guro Hospital \\ Ki Woong Sung \\ Korea University Guro Hospital \\ Hong Hoe Koo \\ Korea University Guro Hospital \\ Eun-Suk Kang \\ Sungkyunkwan University School of Medicine \\ Kang Mo Ahn \\ Sungkyunkwan University School of Medicine \\ Yae-Jean Kim \\ Sungkyunkwan University School of Medicine \\ Keon Hee Yoo \\ Sungkyunkwan University https://orcid.org/0000-0002-5980-7912
}

\section{Research Article}

Keywords: hematopoietic stem cell transplantation, severe combined immunodeficiency, cell count, pediatrics

Posted Date: May 11th, 2021

DOl: https://doi.org/10.21203/rs.3.rs-482023/v1

License: @ (i) This work is licensed under a Creative Commons Attribution 4.0 International License. Read Full License 


\section{Abstract}

Purpose Hematopoietic stem cell transplantation (HSCT) is the standard method of reconstituting immune function in severe combined immunodeficiency (SCID); however, current conditioning recommendations and optimal cell doses lack consensus. In this study, we investigated HSCT outcomes and immune reconstitution, following minimal dose (MD) HSCT in T cell-negative (T-), B cell-positive (B+), natural killer-cell negative (NK-) SCID patients.

Methods We retrospectively reviewed patients with SCID who received HSCT between 2002-2018. Standard dose (SD) and MD were classified based on a total nucleated cell count (TNC) of $1.0 \times 108 / \mathrm{kg}$ or more and less.

Results Seven patients with SCID received HSCT, of which four belonged to the MD group. Patients in the MD group were administered 5 $\mathrm{mL}$ or less of bone marrow without conditioning, with median TNC and CD34+ cell counts of $0.49 \times 108 / \mathrm{kg}$ and $0.62 \times 106 / \mathrm{kg}$, respectively. T cells recovered within a year after HSCT, and immunoglobulin supplementation was discontinued at a median of 3.5 months after HSCT in all MD recipients. All MD recipients were alive without disease recurrence at a median of 126.9 months after HSCT, exhibiting donor chimerism in the range of $10.1 \%-100 \%$. Although grade II-III graft-versus-host diseases occurred, these were manageable in all patients. One of the three patients in the SD group died of cytomegalovirus infection, while another was dependent on intravenous immunoglobulin until 41 months after HSCT.

Conclusion In patients with T-B+NK- SCID, sufficient therapeutic effects were safely obtained with minimal dose of bone marrow infusion without conditioning.

\section{Introduction}

Severe combined immunodeficiency (SCID) collectively refers to a heterogeneous group of rare genetic disorders of the immune system [1]. It is characterized by substantially decreased or functionally deficient T cells, B cells, or natural killer (NK) cells, depending on the nature of the genetic abnormalities. Patients with SCID are vulnerable to life-threatening infections; hence, treatment typically focuses on immune system reconstitution. Although gene therapies have been attempted in patients with certain types of SCID [2-5], allogeneic hematopoietic cell transplantation (HSCT) remains the definitive treatment in most cases.

Owing to the absence of functional T cells in patients with SCID, graft rejection is rare following HSCT. Immunoablative conditioning is often omitted, particularly in human leukocyte antigen-matched sibling donor (MSD) HSCT for T-B+NK- SCID [6, 7]. It is also believed that even a small amount of hematopoietic stem cells (HSCs) can induce immune reconstitution in such cases, as deficient NK cellrelated immunity makes it unable to reject the donor HSCs. However, there is no established minimal effective HSC dose for successful immune reconstitution in patients with SCID.

In light of the above, our center has been using infusions of unmanipulated HSCs in small doses since 2002. According to our clinical experience, only a small number of HSCs are needed for T cell engraftment; moreover smaller doses with lower T cell counts may lower the incidence and severity of graft-versus-host disease (GVHD). In addition, mismatched cells and plasma are not likely to cause clinically significant transfusion reactions when only a small blood volume is infused; hence, the need to deplete red blood cells and plasma is obviated.

In this study, we aimed to determine the clinical and immunological outcomes of T-B+NK-SCID patients transplanted with small doses of cells without conditioning and to compare the outcome with those obtained using standard doses of HSCT. To the best of our knowledge, this paper is the first research article regarding minimal dose (MD) infusion of HSC in SCID patients, showing successful results.

\section{Methods}

\section{Study patients and transplantations}

We retrospectively reviewed a total of seven patients who received allogeneic HSCT for SCID at Samsung Medical Center, Seoul, Korea from 2002-2018. Data on patient demographics; transplantation characteristics; and clinical course information, including survival, infection, and the incidence of GVHD, were obtained. This study was approved by the Institutional Review Board of Samsung Medical Center (IRB No. 2020-03-014). The need for informed consent was waived by the board. 
Evaluation of immune reconstitution following transplantation

We conducted an HSCT engraftment analysis using short tandem repeat (STR)-based chimerism testing on post-treatment days 28,56 , $100,180,365$, and beyond, if needed. The STR-based chimerism analysis was performed using peripheral blood at 56 days and bone marrow (BM) samples at other time points. Lymphocyte subsets, including T cells $\left(\mathrm{CD} 3^{+}\right), \mathrm{B}$ cells $\left(\mathrm{CD} 19^{+}\right)$, NK cells $\left(\mathrm{CD} 16^{+} 56^{+} 3^{-}\right)$and immunoglobulin levels, were assessed on post-treatment days $28,100,180,365$, and beyond, as needed.

\section{Definitions and statistics}

Patients were placed into an MD group or a standard dose (SD) group. MD was defined as a total nucleated cell count (TNC) lower than $1.0 \times 10^{8} / \mathrm{kg}$, while the SD was defined as TNC $1.0 \times 10^{8} / \mathrm{kg}$ or more. Unlike other transplantations, cells are generally infused in quantities to the $10^{\text {th }}$ power for cord blood transplantation (CBT); the MD of CBT was defined as $\mathrm{TNC}<1.0 \times 10^{7} / \mathrm{kg}$.

The diagnosis and grading of GVHD were based on the standard clinical criteria $[8,9]$. Complete donor chimerism was defined as $>99 \%$ of the deoxyribonucleic acid (DNA) in a sample specimen from the recipient being derived from the donor. When 1-99\% of the recipient's DNA was derived from the donor, mixed chimerism was considered to have occurred [10].

T cell count recovery was defined as a $\mathrm{CD}^{+}$count $>800 \mathrm{cells} / \mathrm{mm}^{3}$, while $\mathrm{CD} 4^{+}$and $\mathrm{CD} 8^{+}$recovery were defined as $>400$ cells $/ \mathrm{mm}^{3}$ and 200 cells $/ \mathrm{mm}^{3}$, respectively [11]. B cell count and function recovery were defined as a CD19+ $>400 / \mathrm{mm}^{3}$ and independence from intravenous immunoglobulin (IVIg) therapy. The time to IVIg independence described the time from HSCT to the last day of IVIg infusion.

\section{Results}

\section{Characteristics of study patients and transplantation}

The characteristics of the patients have been summarized in Table 1. A total of seven patients with T-B+NK- SCID received HSCT from 2002-2018. All patients were male, and the median age at transplantation was 4.7 months (range, 2.3-7.0). All seven patients were diagnosed with T-B+NK-SCID using immunological tests. Interleukin-2 receptor y chain deficiency was genetically confirmed in four patients. Genetic testing was not performed in two patients (M1, S2). One patient (S3) underwent next-generation sequencing analysis; however, we could not find disease-causative genetic abnormalities.

Four patients received MD HSC, while three patients received SD HSC. Among the former, three received HSCT from an MSD, while one patient (M3) received the transplantation from a familial mismatched donor (FMMD). Transplantation was performed without conditioning and GVHD prophylaxis in the MD group. Three patients in this group received $5 \mathrm{~mL}$ of BM aspirate, while the remaining patient received $2 \mathrm{~mL}$ of $\mathrm{BM}$ aspirate. The median TNC, $\mathrm{CD} 34^{+}$cells, and $\mathrm{CD}^{+}$cell doses were $0.49($ range, $0.32-0.84) \times 10^{8} / \mathrm{kg}, 0.62$ (range, $0.38-0.84) \times 10^{6} / \mathrm{kg}$, and 0.44 (range, $\left.0.11-1.14\right) \times 10^{7} / \mathrm{kg}$, respectively.

Among the three patients receiving SD HSCT, two received peripheral blood stem cell transplantation from FMMD that was manipulated using the ex vivo $\mathrm{CD}^{+}$T-cell receptor (TCR) a $\beta^{+}$depletion technique without conditioning or GVHD prophylaxis, and the other patient (S3) received mismatched, unrelated CBT with reduced-intensity conditioning. Patient S3, the younger brother of patient S2 and born as a dizygotic twin, received CBT at three months after birth without a Bacillus Calmette-Guérin (BCG) vaccination.

Excluding patient S3, who received transplantation closest to the time of birth, the other six patients all experienced severe infections prior to transplantation. Four patients (M2, M3, M4, and S2) suffered from disseminated BCG infection prior to HSCT. Patient M1 received transplantation while under ventilator care for severe pneumonia at the intensive care unit. Ventilation was discontinued six days after HSCT. Patient M3 suffered rotavirus viremia after vaccination for rotavirus. Patients M4 and S2 developed Pneumocystis jirovecii pneumonia. Patient M4 also experienced recurrent diarrhea. Patient S1 frequently suffered from upper respiratory tract infections and otitis media. Patient S2 had cytomegalovirus (CMV) disease of the lung and central nervous system at the time of SCID diagnosis.

\section{Donor chimerism and survival outcome}

All patients who received MD HSCT showed donor-derived cells that ranged from $7.3 \%-26.4 \%$ at 28 days after HSCT. This range decreased to $1.4-8.7 \% 100$ days after HSCT before gradually increasing to $10.12 \%-100 \%$ at the final evaluation. Although patient M3 
showed $2.7 \%$ donor chimerism 100 days after HSCT, complete donor chimerism was obtained following a stem cell boost with $1 \mathrm{~mL}$ of BM aspirate from the same donor 119 days after the first HSCT for uncontrolled, disseminated BCG infection. The serial STR results of the MD group have been presented in Figure 1. All patients were alive without infections related to disease recurrence at a median of 127 months (range, 21-203 months) after HSCT.

In the SD group, patient S2 experienced primary graft failure and received a second HSCT from the same FMMD 34 days after the first HSCT, albeit unsuccessfully. A third transplantation was performed using unrelated cord blood after busulfan-based conditioning, and complete donor chimerism was accomplished. However, this patient ultimately died of disseminated CMV disease 68 days after the third HSCT, which was refractory to treatment with ganciclovir (Roche Korea), foscarnet (Fresenius Kabi), and CMV immunoglobulin (Biotest pharm). Patient S1 and S3 achieved donor chimerism of $48.11 \%$ and $88.72 \%$ at 3 years and 1year after HSCT, respectively.

\section{Graft-versus-host disease}

The patient outcomes after HSCT have been summarized in Table 2. Three of four patients in the MD group experienced grade II acute GVHD. One case was resolved without specific treatment, while the other two patients underwent GVHD treatment with corticosteroids and cyclosporine. Patient M3 developed extensive chronic GVHD, involving the lungs, skin, and mouth, after received FMMD transplantation and boost infusion. He was treated with corticosteroid and rituximab but became free from immunosuppressive agents 63 months after HSCT.

Two of the three SD HSCT recipients experienced acute GVHD of grades II and III, respectively. The grade III patient recovered following corticosteroid treatment.

\section{Immune reconstitution after HSCT}

Changes in the numbers of various immune cells and serum immunoglobulin levels of each patient after HSCT have been presented in Figure 2 and Supplementary Table S1. Patient M3, who underwent immunosuppressive treatments for extensive chronic GVHD, had a reduced T cell count 1 year after HSCT. The B cell count decreased to $<200$ cells $/ \mathrm{mm}^{3}$ in patients M1 and M3 during the first 3 months after HSCT; however, the patients recovered after 6 months and 1 year, respectively. IVlg supplementation was discontinued in all MD patients at a median of 4 months (range, 1-37 months) following HSCT.

In the SD group, both the T cell and B-cell counts recovered in patient S1 6 months after HSCT; however, IgG, IgA, and IgM did not reach the normal range. This patient is on IVIg supplementation at 41 months after HSCT. Patient S3, who underwent CBT after conditioning, achieved $B$ cell and $T$ cell recovery at 3 and 6 months, respectively.

\section{Discussion}

The optimal number of TNC and CD34 ${ }^{+}$cells required for HSCT in SCID patients has not yet been established, but previous studies have reported higher doses of infused cells than those used in this study. Reports by the Primary Immune Deficiency Treatment Consortium (PIDTC) and European Blood and Marrow Transplant Society (EBMT) have used doses with median TNCs of 5.5-7.98 $\times 10^{8} / \mathrm{kg}$ for MSD and $4.8 \times 10^{8} / \mathrm{kg}$ in matched unrelated donor HSCTs for SCID $[12,13]$. In our study, the MD group received infusions with lower median TNC doses than the smallest doses reported in previous studies. All MD HSCT patients survived with no clinical evidence of disease recurrence. Sufficient immune reconstitution was accomplished, and all patients discontinued IVIg supplementation.

Our strategy of infusing low doses of HSC without conditioning had several implications.First, successful transplantation in T-B+NKSCID can be determined not by complete engraftment, but by recovery of immunity and a minimal amount of stem cell infusion without conditioning is sufficient to achieve it. Conditioning treatment is used to create BM niche space and achieve immune suppression in order to prevent graft rejection. However, the need for conditioning in patients with SCID is debated, as T cell reconstitution can be achieved without conditioning [14, 15]. In NK+ SCID patients, the BM space is full of HSCs and precursor B-lymphocytes, and the thymus is full of precursor T-lymphocytes; thus, conditioning is required to empty these niches to facilitate engraftment and consequent $\mathrm{B}$ - and T-lymphocyte progenitor development [6, 16]. In contrast, T-B+NK-SCID arises following impaired T- and NK cell development. The vacant $\mathrm{BM}$ niches of such patients are thought to be receptive and permissive of the engraftment of donor-derived precursors [6]. In this study, three patients in the MD HSC group showed stable mixed chimerism, but none experienced graft rejection. As lineage-specific donor chimerism analysis was not measured in our study, the engraftment of each cell lineage was unknown. However, our data showed that an extremely low level of unsorted donor chimerism in the early post-HSCT phase could induce durable donor engraftment, 
suggesting the possibility of a graft-versus-marrow effect. In addition, the chimerism level displayed dynamic changes, indicating that chimerism alone should not be used as the sole indicator of graft failure, especially when concomitant and clinically relevant immune reconstitution is observed. Unlike HSCT in hematologic malignancies, in which mixed chimerism is a predictor of rejection, SCID is thought to be correctable with mixed chimerism; furthermore, complete donor chimerism may be unnecessary for cure.[17, 18] Instead, mixed chimerism is associated with a lesser degree of GVHD than complete donor chimerism.[18] Although most patients in the MD group showed mixed chimerism, their cellular and humoral immune reconstitutions were excellent even when extremely low levels of donor chimerism were present. Although donor chimerism was only $1.4 \%$ in patient M1 100 days after HSCT, lymphocyte counts were normal, and the B cell count was only slightly low. The PIDTC study demonstrated that the presence of higher CD $4^{+}$cell counts (above $500 / \mathrm{mm}^{3}$ ) at 6 and 12 months post-HSCT was predictive of improved long-term T cell reconstitution and better long-term overall survival.[19] In our study, CD $4^{+}$counts exceeded $500 / \mathrm{mm}^{3}$ at either 6 or 12 months after MD HSCT in all patients. In addition, all MD patients achieved independence from IVlg therapy post-HSCT, with three patients becoming independent in 4 months. Recovery of immunity and reduction of infection, the main goals of HSCT in SCID, were achieved using MD HSCT. One patient in this study (S2) died of infectious cause, who was a recipient of SD HSC.

Second, MD HSC infusion holds the advantage of a low incidence of transplantation-related morbidity in terms of infection, long-term GVHD, and impaired growth or fertility. Conditioning toxicity is one of the major causes of death in SCID patients [19, 20]. In countries where newborn screening testing for SCID is not used, the majority of cases without a family history of SCID are complicated by serious infection before HSCT can be administered. Four patients in our study developed disseminated BCG infection before HSCT since BCG administration is routinely recommended during the neonatal period in Korea. In addition, one patient experienced rotavirus infection after live attenuated rotavirus vaccine administration. In these cases, the use of conditioning and immunosuppressive agents for GVHD prophylaxis can actually exacerbate the infection. We found that the administration of MD HSCT without conditioning or GVHD prophylaxis was able to control pre-existing infectious complications.

By reducing the HSC infusion dose, the risk of GVHD decreases due to lower donor T cell doses. In this study, the T cell count of the infusion was almost a tenth of those used in the PIDTC and EBMT reports [12]. There were no patients with grade III or IV acute GVHD following MD HSCT, and those with grade II acute GVHD were easily managed. However, caution is still warranted, as extensive chronic GVHD developed in one patient who underwent MD HSCT from an FMMD and an HSC boost.

GVHD is one of the major causes of mortality during HSCT in patients with primary immune deficiencies [17]; moreover, and the incidence in SCID has been reported to be $28.3 \%-55.3 \%[12,14,19,21]$. Unlike patients with hematologic malignancies, who may benefit from the graft-versus-leukemia effect of donor cells, SCID patients derive no clinical benefit from GVHD. On the other hand, the increased incidence of viral infections and poor immune recovery associated with GVHD prophylaxis are clinically concerning. Our MD HSCT strategy, coupled with a lack of conditioning-induced tissue damage, likely rendered routine GVHD prophylaxis unnecessary.

Third, the MD HSCT method is simple, safe, and accessible in the treatment of SCID. Only $5 \mathrm{~mL}$ of BM aspirate is required from donors, and the treatment can be administered to recipients at bedside, thereby avoiding delays arising during the scheduling of an operation room. Since conditioning is omitted, the need for specialized facilities with laminar flow systems to protect HSCT recipients from contagious pathogens is not mandatory. This could be securely tried even in patients suffering from serious infections and those living in resource-limited countries. Patient M1 underwent HSCT at the intensive care unit with mechanical ventilator support and had no apparent complications. Additionally, if chimerism is not adequately achieved after MD HSCT, an additional boost using a small amount of HSCs is possible. Patient M3 underwent MD HSCT from FMMD, receiving an additional $1 \mathrm{~mL}$ of BM infusion for poor graft performance; complete chimerism occurred thereafter.

There were some limitations to our study. This was a retrospective descriptive study using a small population and, as such, statistically significant conclusions likely cannot be drawn. Moreover, genetic mutational profiles were not available in some patients, and lineagespecific chimerism could not be tested.

Despite these limitations, the authors believe this to be the first study to report detailed HSCT information pertaining to T-B+NK- SCID patients treated with small doses of BM-derived HSCs without conditioning. Based on our data, the minimal effective dose required for HSCT without conditioning is likely to be much lower than those used in current practices. In conclusion, this study demonstrated the feasibility of MD HSCT without conditioning in T-B+NK-SCID patients.

\section{Declarations}




\section{Funding}

This research did not receive any specific grant from funding agencies in the public, commercial, or not-for-profit sectors.

\section{Conflicts of Interest}

None of the authors have any conflicts of interest to report.

Availability of data and material

The data that support the study findings are available from the corresponding author upon reasonable request.

\section{Authors' contributions}

KH Yoo and HH Koo designed the research study. HW Cho, JW Lee, and KW Sung contributed for data collection. ES Kang, GM Ahn, Y Kim supported laboratory study and resources. ES Yi and HY Ju analyzed the data. ES Yi and HY Ju wrote the original draft. All of the authors reviewed and edited the paper. KH Yoo supervised the study.

\section{Ethics approval}

This study was approved by the Institutional Review Board of Samsung Medical Center (IRB No. 2020-03-014).

\section{Consent to participate}

The need for informed consent was waived by the board.

\section{Consent for publication}

The need for informed consent was waived by the board.

\section{Acknowledgements}

This research did not receive any specific grant from funding agencies in the public, commercial, or not-for-profit sectors.

\section{Authorship Contributions}

$\mathrm{KH}$ Yoo and HH Koo designed the research study. HW Cho, JW Lee, and KW Sung contributed for data collection. ES Kang, GM Ahn, Y Kim supported laboratory study and resources. ES Yi and HY Ju analyzed the data. ES Yi and HY Ju wrote the original draft. All of the authors reviewed and edited the paper. KH Yoo supervised the study

\section{Disclosure of Conflicts of Interest}

None of the authors have any conflicts of interest to report.

\section{References}

1. Picard C, Bobby Gaspar H, Al-Herz W, Bousfiha A, Casanova JL, Chatila T, Crow YJ, Cunningham-Rundles C, Etzioni A, Franco JL, Holland SM, Klein C, Morio T, Ochs HD, Oksenhendler E, Puck J, Tang MLK, Tangye SG, Torgerson TR, Sullivan KE. International Union of Immunological Societies: 2017 Primary Immunodeficiency Diseases Committee Report on Inborn Errors of Immunity. J Clin Immunol. 2018;38:96-128.

2. Ferrua F, Cicalese MP, Galimberti S, Giannelli S, Dionisio F, Barzaghi F, Migliavacca M, Bernardo ME, Calbi V, Assanelli AA, Facchini M, Fossati C, Albertazzi E, Scaramuzza S, Brigida I, Scala S, Basso-Ricci L, Pajno R, Casiraghi M, Canarutto D, Salerio FA, Albert MH, Bartoli A, Wolf HM, Fiori R, Silvani P, Gattillo S, Villa A, Biasco L, Dott C, Culme-Seymour EJ, van Rossem K, Atkinson G, Valsecchi MG, Roncarolo MG, Ciceri F, Naldini L, Aiuti A. Lentiviral haemopoietic stem/progenitor cell gene therapy for treatment of WiskottAldrich syndrome: interim results of a non-randomised, open-label, phase 1/2 clinical study. Lancet Haematol. 2019;6:e239-e53.

3. Mamcarz E, Zhou S, Lockey T, Abdelsamed H, Cross SJ, Kang G, Ma Z, Condori J, Dowdy J, Triplett B, Li C, Maron G, Aldave Becerra JC, Church JA, Dokmeci E, Love JT, da Matta Ain AC, van der Watt H, Tang X, Janssen W, Ryu BY, De Ravin SS, Weiss MJ, 
Youngblood B, Long-Boyle JR, Gottschalk S, Meagher MM, Malech HL, Puck JM, Cowan MJ, Sorrentino BP. Lentiviral Gene Therapy Combined with Low-Dose Busulfan in Infants with SCID-X1. N Engl J Med. 2019;380:1525-34.

4. Aiuti A, Cattaneo F, Galimberti S, Benninghoff U, Cassani B, Callegaro L, Scaramuzza S, Andolfi G, Mirolo M, Brigida I, Tabucchi A, Carlucci F, Eibl M, Aker M, Slavin S, Al-Mousa H, Al Ghonaium A, Ferster A, Duppenthaler A, Notarangelo L, Wintergerst U, Buckley RH, Bregni M, Marktel S, Valsecchi MG, Rossi P, Ciceri F, Miniero R, Bordignon C, Roncarolo MG. Gene therapy for immunodeficiency due to adenosine deaminase deficiency. N Engl J Med. 2009;360:447-58.

5. Cicalese MP, Ferrua F, Castagnaro L, Pajno R, Barzaghi F, Giannelli S, Dionisio F, Brigida I, Bonopane M, Casiraghi M, Tabucchi A, Carlucci F, Grunebaum E, Adeli M, Bredius RG, Puck JM, Stepensky P, Tezcan I, Rolfe K, De Boever E, Reinhardt RR, Appleby J, Ciceri F, Roncarolo MG, Aiuti A. Update on the safety and efficacy of retroviral gene therapy for immunodeficiency due to adenosine deaminase deficiency. Blood. 2016;128:45-54.

6. Hassan A, Lee P, Maggina P, Xu JH, Moreira D, Slatter M, Nademi Z, Worth A, Adams S, Jones A, Cale C, Allwood Z, Rao K, Chiesa R, Amrolia P, Gaspar H, Davies EG, Veys P, Gennery A, Qasim W. Host natural killer immunity is a key indicator of permissiveness for donor cell engraftment in patients with severe combined immunodeficiency. J Allergy Clin Immunol. 2014;133:1660-6.

7. Railey MD, Lokhnygina Y, Buckley RH. Long-term clinical outcome of patients with severe combined immunodeficiency who received related donor bone marrow transplants without pretransplant chemotherapy or post-transplant GVHD prophylaxis. $J$ Pediatr. 2009;155:834-40 e1.

8. Przepiorka D, Weisdorf D, Martin P, Klingemann HG, Beatty P, Hows J, Thomas ED. 1994 Consensus Conference on Acute GVHD Grading. Bone Marrow Transplant. 1995;15:825-8.

9. Horwitz ME, Sullivan KM. Chronic graft-versus-host disease. Blood Rev. 2006;20:15-27.

10. Baron F, Sandmaier BM. Chimerism and outcomes after allogeneic hematopoietic cell transplantation following nonmyeloablative conditioning. Leukemia. 2006;20:1690-700.

11. Cavazzana-Calvo M, Carlier F, Le Deist F, Morillon E, Taupin P, Gautier D, Radford-Weiss I, Caillat-Zucman S, Neven B, Blanche S, Cheynier R, Fischer A, Hacein-Bey-Abina S. Long-term T-cell reconstitution after hematopoietic stem-cell transplantation in primary Tcell-immunodeficient patients is associated with myeloid chimerism and possibly the primary disease phenotype. Blood. 2007;109:4575-81.

12. Dvorak CC, Hassan A, Slatter MA, Honig M, Lankester AC, Buckley RH, Pulsipher MA, Davis JH, Gungor T, Gabriel M, Bleesing JH, Bunin N, Sedlacek P, Connelly JA, Crawford DF, Notarangelo LD, Pai SY, Hassid J, Veys P, Gennery AR, Cowan MJ. Comparison of outcomes of hematopoietic stem cell transplantation without chemotherapy conditioning by using matched sibling and unrelated donors for treatment of severe combined immunodeficiency. J Allergy Clin Immunol. 2014;134:935-43.e15.

13. Heimall J, Logan BR, Cowan MJ, Notarangelo LD, Griffith LM, Puck JM, Kohn DB, Pulsipher MA, Parikh S, Martinez C, Kapoor N, O'Reilly R, Boyer M, Pai SY, Goldman F, Burroughs L, Chandra S, Kletzel M, Thakar M, Connelly J, Cuvelier G, Davila Saldana BJ, Shereck E, Knutsen A, Sullivan KE, DeSantes K, Gillio A, Haddad E, Petrovic A, Quigg T, Smith AR, Stenger E, Yin Z, Shearer WT, Fleisher T, Buckley RH, Dvorak CC. Immune reconstitution and survival of 100 SCID patients post-hematopoietic cell transplant: a PIDTC natural history study. Blood. 2017;130:2718-27.

14. Pai SY, Logan BR, Griffith LM, Buckley RH, Parrott RE, Dvorak CC, Kapoor N, Hanson IC, Filipovich AH, Jyonouchi S, Sullivan KE, Small TN, Burroughs L, Skoda-Smith S, Haight AE, Grizzle A, Pulsipher MA, Chan KW, Fuleihan RL, Haddad E, Loechelt B, Aquino VM, Gillio A, Davis J, Knutsen A, Smith AR, Moore TB, Schroeder ML, Goldman FD, Connelly JA, Porteus MH, Xiang Q, Shearer WT, Fleisher TA, Kohn DB, Puck JM, Notarangelo LD, Cowan MJ, O'Reilly RJ. Transplantation outcomes for severe combined immunodeficiency, 2000-2009. N Engl J Med. 2014;371:434-46.

15. Haddad E, Leroy S, Buckley RH. B-cell reconstitution for SCID: should a conditioning regimen be used in SCID treatment? J Allergy Clin Immunol. 2013;131:994-1000.

16. Gennery AR, Slatter MA. Chemotherapy-free conditioning: one step closer. Blood. 2014;124:838-40.

17. Yi ES, Choi YB, Lee NH, Lee JW, Sung KW, Koo HH, Kang ES, Kim YJ, Yoo KH. Allogeneic Hematopoietic Cell Transplantation in Patients with Primary Immunodeficiencies in Korea: Eleven-Year Experience in a Single Center. J Clin Immunol. 2018;38:757-66.

18. Rousso SZ, Shamriz O, Zilkha A, Braun J, Averbuch D, Or R, Weintraub M, Revel-Vilk S, Stepensky P. Hematopoietic Stem Cell Transplantations for Primary Immune Deficiencies: 3 Decades of Experience From a Tertiary Medical Center. J Pediatr Hematol Oncol. 2015;37:e295-300.

19. Haddad E, Logan BR, Griffith LM, Buckley RH, Parrott RE, Prockop SE, Small TN, Chaisson J, Dvorak CC, Murnane M, Kapoor N, Abdel-Azim H, Hanson IC, Martinez C, Bleesing JJH, Chandra S, Smith AR, Cavanaugh ME, Jyonouchi S, Sullivan KE, Burroughs L,

Page $7 / 10$ 
Skoda-Smith S, Haight AE, Tumlin AG, Quigg TC, Taylor C, Davila Saldana BJ, Keller MD, Seroogy CM, Desantes KB, Petrovic A, Leiding JW, Shyr DC, Decaluwe H, Teira P, Gillio AP, Knutsen AP, Moore TB, Kletzel M, Craddock JA, Aquino V, Davis JH, Yu LC, Cuvelier GDE, Bednarski JJ, Goldman FD, Kang EM, Shereck E, Porteus MH, Connelly JA, Fleisher TA, Malech HL, Shearer WT, Szabolcs P, Thakar MS, Vander Lugt MT, Heimall J, Yin Z, Pulsipher MA, Pai SY, Kohn DB, Puck JM, Cowan MJ, O'Reilly RJ, Notarangelo LD. SCID genotype and 6-month posttransplant CD4 count predict survival and immune recovery. Blood. 2018;132:1737-49.

20. Heimall J, Logan BR, Cowan MJ, Notarangelo LD, Griffith LM, Puck J, Parikh S, O'Reilly RJ, Pai S-Y, Hanson IC, Martinez C, Pulsipher MA, Kapoor N, Goldman F, Kletzel M, Filipovich L, Cuvellier G, Thakar M, Burroughs L, Knudsen A, Connelly JA, Quigg TC, Smith AR, Sullivan K, Loechelt BJ, Gillio AP, Haddad E, Kohn DB, Fleisher T, Shearer W, Dvorak CC, Buckley RH. Early Hematopoietic Cell Transplant (HCT) Outcomes of Children with Severe Combined Immunodeficiency Disease (SCID): The First Seventy Four Patients of the Primary Immune Deficiency Treatment Consortium (PIDTC) Prospective Study 6901. Biology of Blood and Marrow Transplantation. 2015;21:S289-S91.

21. Grunebaum E, Mazzolari E, Porta F, Dallera D, Atkinson A, Reid B, Notarangelo LD, Roifman CM. Bone marrow transplantation for severe combined immune deficiency. Jama. 2006;295:508-18.

\section{Tables}

Table 1. Characteristics of study patients and transplantation

\begin{tabular}{|c|c|c|c|c|c|c|c|c|c|c|c|c|c|c|}
\hline No. & Sex & $\begin{array}{c}\text { Age at } \\
\text { HCT } \\
\text { (months) }\end{array}$ & $\begin{array}{l}\text { Genetic } \\
\text { type }\end{array}$ & $\begin{array}{l}\text { Donor } \\
\text { type }\end{array}$ & $\begin{array}{l}\text { HLA } \\
\text { match }\end{array}$ & $\begin{array}{l}\text { Stem } \\
\text { cell } \\
\text { source }\end{array}$ & $\begin{array}{c}\text { ABO type, } \\
\text { Donor/Recipient }\end{array}$ & $\begin{array}{l}\text { Infused } \\
\text { volume } \\
\text { (ml) }\end{array}$ & $\begin{array}{c}\text { TNC } \\
\text { dose } \\
\left(\times 10^{8}\right. \\
/ \mathrm{kg})\end{array}$ & $\begin{array}{c}\text { CD34 } \\
\text { cell } \\
\text { dose } \\
\left(\times 10^{6}\right. \\
/ \mathrm{kg})\end{array}$ & $\begin{array}{c}\text { CD3 } \\
\text { cell } \\
\text { dose } \\
\left(\times 10^{7}\right. \\
/ \mathrm{kg})\end{array}$ & $\begin{array}{l}\text { Conditioning } \\
\text { regimen }\end{array}$ & $\begin{array}{c}\text { Ex-vivo } \\
\text { TCR } \alpha \beta \\
\text { depletion }\end{array}$ & $\begin{array}{c}\text { GVHD } \\
\text { prophylaxis }\end{array}$ \\
\hline
\end{tabular}

\begin{tabular}{|c|c|c|c|c|c|c|c|c|c|c|c|c|c|c|}
\hline \multicolumn{15}{|c|}{ Minimal cell dose } \\
\hline M1 & M & 5 & NA & MSD & $8 / 8$ & $\mathrm{BM}$ & $\mathrm{O}+/ \mathrm{O}+$ & 5 & 0.84 & 0.67 & 1.14 & None & No & None \\
\hline M2 & M & 4 & $I L 2 R G$ & MSD & $8 / 8$ & $\mathrm{BM}$ & $\mathrm{A}+/ \mathrm{A}+$ & 5 & 0.32 & 0.38 & 0.37 & None & No & None \\
\hline M3 & M & 5 & $I L 2 R G$ & FMMD & $5 / 10$ & $\mathrm{BM}$ & $\mathrm{B}+/ \mathrm{B}+$ & 2 & 0.43 & 0.57 & 0.11 & None & No & None \\
\hline M4 & M & 7 & $I L 2 R G$ & MSD & $10 / 10$ & $\mathrm{BM}$ & $\mathrm{AB}+/ \mathrm{A}+$ & 5 & 0.54 & 0.84 & 0.51 & None & No & None \\
\hline \multicolumn{15}{|c|}{ Standard cell dose } \\
\hline S1 & M & 4 & $I L 2 R G$ & FMMD & $5 / 10$ & $\mathrm{~PB}$ & $\mathrm{~A}+/ \mathrm{A}+$ & 55 & 8.57 & 5.10 & $0.02^{\dagger}$ & None & Yes & None \\
\hline S2 & M & 4 & NA & FMMD & $6 / 10$ & $\mathrm{~PB}$ & $\mathrm{~A}+/ \mathrm{A}+$ & 90 & 12.87 & 6.85 & $0^{\dagger}$ & None & Yes & None \\
\hline S3 & M & 2 & $\mathrm{NA}^{\ddagger}$ & UCB & $9 / 10$ & $\mathrm{CB}$ & $\mathrm{O}+/ \mathrm{A}+$ & 23 & 0.90 & 0.10 & 1.59 & BuFluATG & No & Yes \\
\hline
\end{tabular}

${ }^{\dagger} \mathrm{TCR} \alpha^{+} \beta^{+} \mathrm{T}$ cell depletion, ${ }^{\ddagger}$ Next-generation sequencing was performed for patient S3, but no significant relevant mutation was detected.

HSCT, hematopoietic cell transplantation; HLA, human leukocyte antigen; TNC, total nucleated cell count; GVHD, graft-versus-host disease; NA, not available; MSD, matched sibling donor; FMMD, familial mismatched donor transplantation; UCB, unrelated cord blood; BM, bone marrow; PB, peripheral blood; CB, cord blood; Bu, busulfan; Cy, cyclophosphamide; CSA, cyclosporine; MTX, methotrexate

Table 2. Outcomes after HCT 


\begin{tabular}{ccccccccc}
\hline $\begin{array}{c}\text { Case } \\
\text { No. }\end{array}$ & $\begin{array}{c}\text { Additional HCT or } \\
\text { stem cell boost }\end{array}$ & $\begin{array}{c}\text { Grade of } \\
\text { Acute } \\
\text { GVHD }\end{array}$ & $\begin{array}{c}\text { Chronic } \\
\text { GVHD }\end{array}$ & Survival & $\begin{array}{c}\text { Cause of } \\
\text { death }\end{array}$ & $\begin{array}{c}\text { Free } \\
\text { of } \\
\text { IVIg }\end{array}$ & $\begin{array}{c}\text { Months from } \\
\text { HSCT at Last } \\
\text { IVIg }\end{array}$ & $\begin{array}{c}\text { CMV } \\
\text { infection }\end{array}$ \\
\hline
\end{tabular}

\begin{tabular}{|c|c|c|c|c|c|c|c|c|c|c|}
\hline \multicolumn{11}{|c|}{ Minimal cell dose } \\
\hline M1 & No & II & No & Alive & & Yes & 4 & No & No & 203 \\
\hline M2 & No & No & No & Alive & & Yes & 1 & No & No & 127 \\
\hline M3 & $\mathrm{Yes}^{\dagger}$ & II & Extensive & Alive & & Yes & 37 & No & No & 72 \\
\hline M4 & No & II & No & Alive & & Yes & 3 & No & No & 21 \\
\hline \multicolumn{11}{|c|}{ Standard cell dose } \\
\hline S1 & No & III & No & Alive & - & No & 42 & No & No & 42 \\
\hline $\mathrm{S}^{\ddagger}$ & Yes & II & $\mathrm{N} / \mathrm{A}$ & Deceased & $\begin{array}{l}\text { Refractory } \\
\text { CMV disease }\end{array}$ & NA & 5 & Yes & Yes & 5 \\
\hline S3 & No & No & No & Alive & & Yes & 2 & No & No & 21 \\
\hline
\end{tabular}

${ }^{\dagger}$ Patient M3 received $1 \mathrm{ml}$ of additional bone marrow without conditioning. ${ }^{\ddagger}$ Patient S2 patient received second and third HCT treatments. HCT, hematopoietic cell transplantation; CMV, cytomegalovirus; GVHD, graft-versus-host disease; IVIg, intravenous immunoglobulin, N/A, not applicable

\section{Figures}

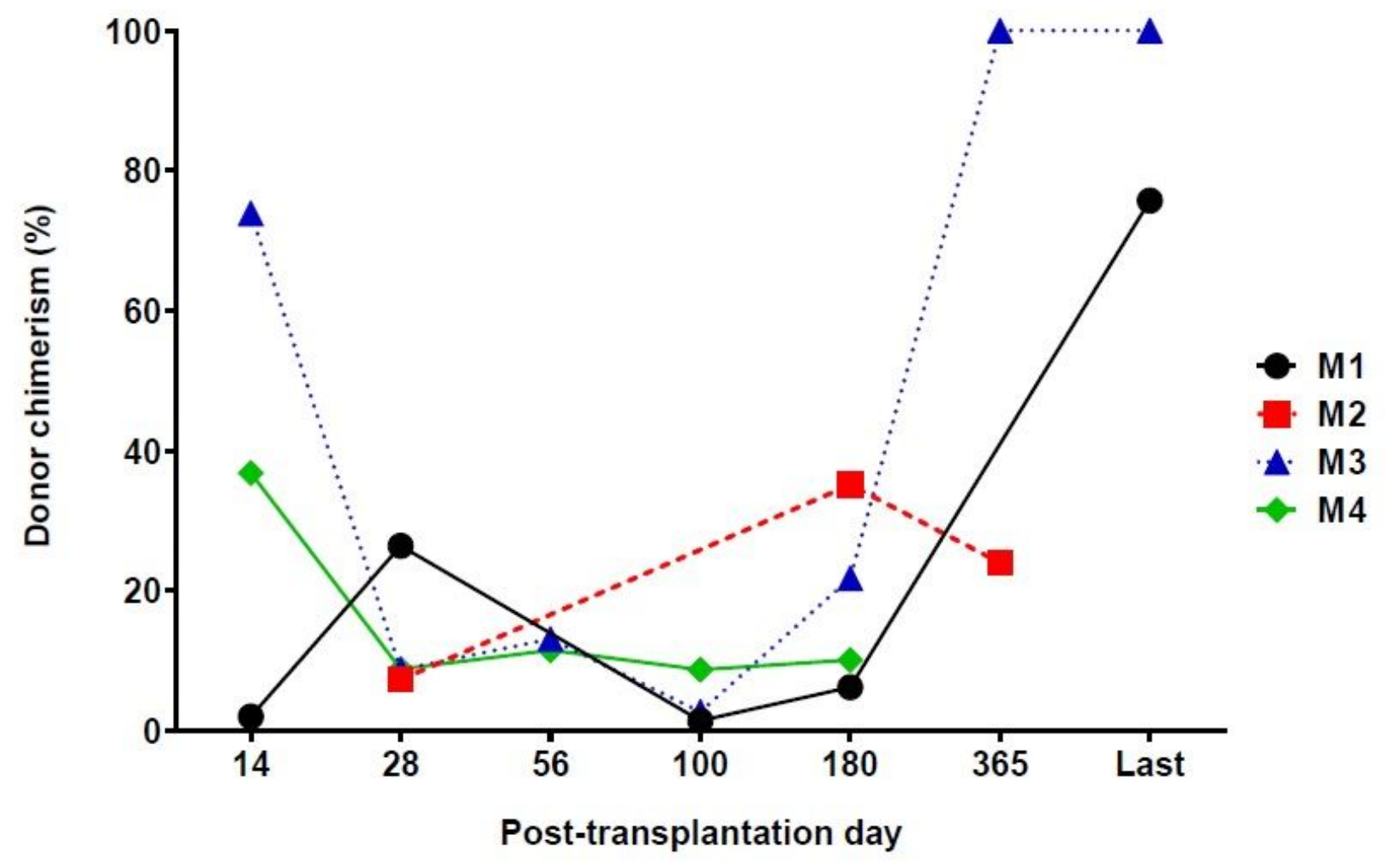

M1

M2

M3

M4
2

73.9

36.8
26.4

7.3

8.7

8.8
1.4

13.1

11.5
27
6.2

35.1

21.8

8.7

10.1

75.7 (17 yr)

24

100

100 (16 mo)

Figure 1 
Changes in donor chimerism of recipients receiving minimal doses of hematopoietic stem cells after transplantation.

(A)

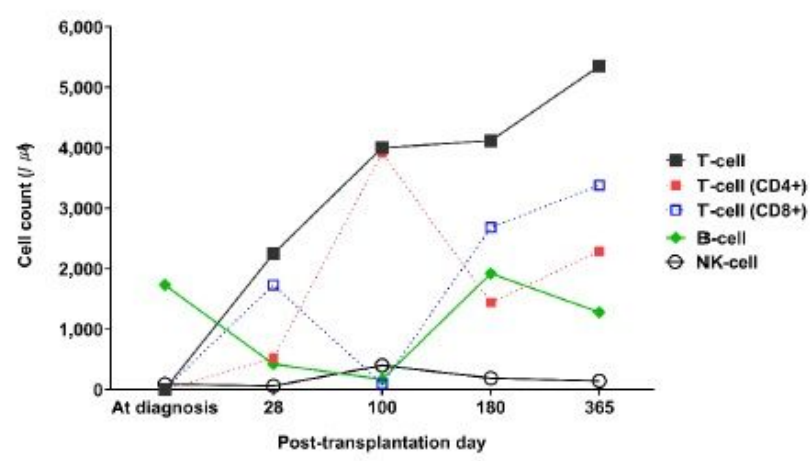

Donor chimerism $(\%)$

$2 \quad 26.4$

1.4

6.2

75.7 (17 yr)

(C)

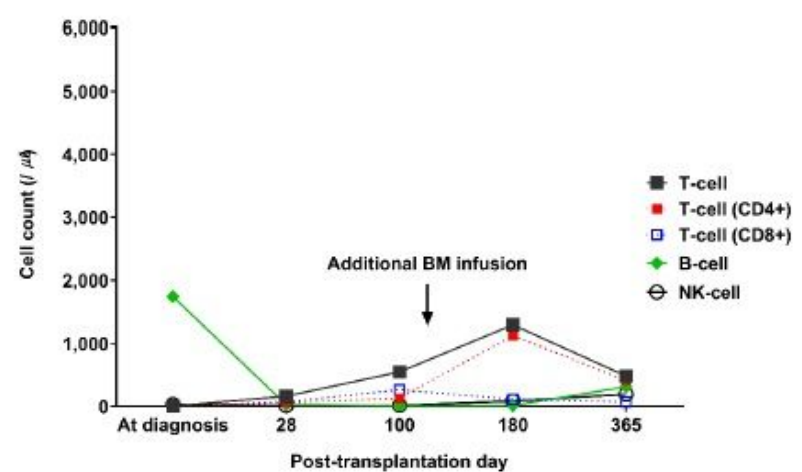

Donor chimerism (\%) $\begin{array}{llll}73.9 & 8.7 & 13.1 & 2.7\end{array}$
(B)

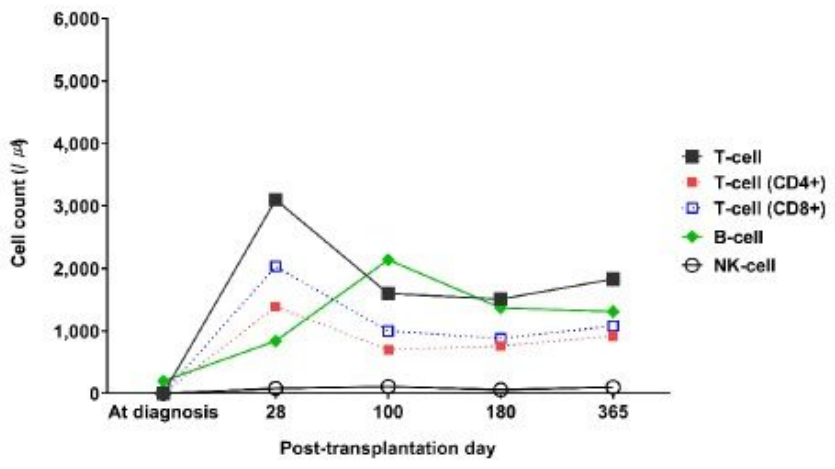

Donor chimerism (\%)

7.3

$35.1 \quad 24$

(D)

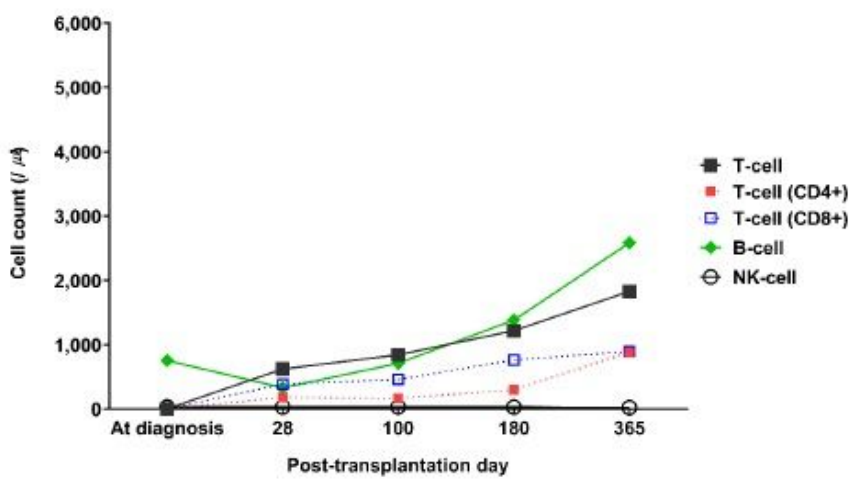

Donor chimerism (\%)

10.

\section{Figure 2}

Changes in the numbers of peripheral immune cells in recipients receiving minimal dose of hematopoietic stem cells transplantation. A-D indicate patients M1-M4, respectively. 